\title{
Gendered and Contextual Factors in the Design of Integrated Pest Management (IPM) Programs for Tomato Growers in East Africa
}

\author{
Dr. E. Wairimu Mwangi (Corresponding Author) \\ University of North Carolina at Charlotte, Department of Sociology \\ Fretwell 476, 9201 University City Blvd., Charlotte, NC 28223, USA \\ Tel: 1-614-937-4154. E-mail: emwangi1@uncc.edu
}

Dr. J. Mark Erbaugh

The Ohio State University, International Programs in Agriculture 113 Agricultural Building, 2120 Fyffe Road, Columbus, OH 43210, USA

\begin{abstract}
Dr. Kallunde Sibuga
Sokoine University of Agriculture, Department of Crop Science and Production P.O Box 3005, Morogoro, Tanzania
\end{abstract}

Dr. Amon Maerere

Sokoine University of Agriculture, Department of Crop Science and Production P.O Box 3005, Morogoro, Tanzania

Dr. Monica Waiganjo

Kenya Agricultural Research Institute (KARI), Thika

P.O Box 220-01000, Thika, Kenya

Received: June 13, 2015 Accepted: July 3, 2015 Published: August 7, 2015

doi:10.5296/ijssr.v3i2.7818 URL: http://dx.doi.org/10.5296/ijssr.v3i2.7818 


\section{Abstract}

The Integrated Pest Management (IPM) Collaborative Research Support Program in East Africa has been using a farmer participatory IPM strategy with small-scale tomato growers at on-farm research sites in Kenya and Tanzania since 2004. Understanding local farmer knowledge of agricultural production, including both gendered and contextual factors, is a hallmark of participatory approaches, and important to the design and development of appropriate location-specific IPM technologies. The purpose of this study was to compare and contrast gender and contextual influences on tomato production farm-level decision-making and marketing practices. The results indicate that regardless of context, gender influenced access to resources and this influenced production quantity and decision-making. However, contextual differences predominated suggesting that "one-size does not fit all" and that planned interventions need to be tailored to specific contexts in which gender relations unfold. Contextual similarities in the production of higher value marketed horticultural crops, including female cash crop production and the prevalent use of synthetic pesticides and fertilizers, provides evidence that the gender-specific nature of traditional African farming is transitioning. That extension agents were relatively minor sources of information suggests that horticultural cash crop production is an important contextual basis for differentiating the demand for IPM programs.

Keywords: gender, IPM, contextual factors, extension

\section{Introduction}

The argument that gender matters in the design and implementation of agricultural development programs acknowledges women's important contribution to agricultural production in sub-Saharan Africa (Blackden, Canagarajah, Klasen, \& Lawson, 2005; Boserup, 1970; Erbaugh, Donnermyer, Amujal, \& Kyamanywa, 2003; Food and Agriculture Organization (FAO), 2011; Quisumbing et al., 2014). Despite their significant contribution to agriculture, it is often asserted that women farmers have often not benefitted from agricultural development efforts and that their productivity continues to lag behind that of male farmers (Boserup, 1970; FAO, 2011; Future Harvest, 2004; Saito, Spurling, \& Mekonnen, 1994; Quisumbing et al., 2014). Gender can influence access to production resources, new information, and support services, which will in-turn, affect production methods, adoption of agricultural innovations, and on-farm decision-making (Doss \& Morris, 2001; Doss, 2001; Meinzen-Dick et al., 2011; Saito et al., 1994). Failure to uncover and examine gendered differences in production relations has led to project failures and inequitable and unsustainable development. Gender analyses are advocated to reveal the connections between gender relations and the development problem to be solved.

Development practitioners have also come to realize that there is enormous complexity and heterogeneity in the way gender influences agricultural decision-making and production and that few lessons are applicable across contexts (Doss, 2001; Hamilton, 2000; Roos \& Gladwin, 2000; Spring, 2000; Meinzen-Dick et al., 2011; Stone \& Stone, 2000). Certain aspects of societal gender relations may be more important in different contexts and vary according to the level of development, patterns and practices of agricultural production, and 
degree of market integration and participation. Generalizing about gender relations from one context to the other may obscure variability and lead to false conclusions and policy recommendations. Thus, to improve agricultural development efforts the context in which development efforts occur, must take into account local system variability including the role of women in agricultural production.

The Integrated Pest Management Collaborative Research Support Program (IPM CRSP) in East Africa has been using a farmer participatory IPM approach with small-scale tomato growers at on-farm research sites in Kenya and Tanzania since 2004. The program's main objectives have been to develop alternative pest management strategies that reduce the use of synthetic pesticides and improve the production of tomato (Lycopersicon esculentum), a high-value marketed crop that contributes to improved household nutrition and livelihoods in both countries. Understanding local farmer knowledge of agricultural production is a hallmark-of participatory approaches and the development and dissemination of appropriate location-specific technologies. Since the main objective of the IPM CRSP was to develop IPM strategies for tomato producers in different contexts it was important to understand both gendered and contextual factors that might impact tomato production and the design and delivery of IPM strategies and interventions.

\subsection{Purpose and Objectives}

The purpose of the study was to compare and contrast gender and contextual influences on tomato production, farm-level decision-making, and marketing practices, and to use this information to improve IPM program design and delivery.

The specific objectives were to examine gender and contextual socio-demographic differences; the impact of gender on farm-level decision-making and marketing practices; the impact of context on farm-level decision-making and marketing practices; and then to apply this knowledge to improve IPM program design and delivery for tomato growers at research sites in Kenya and Tanzania.

\section{Data Source and Methods}

This study utilized data from baseline surveys conducted with tomato growers at IPM CRSP research sites in Mwea, Kenya and Morogoro, Tanzania in 2006 (Waiganjo et al., 2006; Sibuga, Maerere, Mwajombe, Kovach, \& Erbaugh, 2006). These two sites represent different contexts for tomato production. A structured questionnaire was collectively designed by a multi-disciplinary team of IPM CRSP investigators at a workshop held in Morogoro, Tanzania in March of 2006. The instrument was pre-tested and adjusted with four farmers at each site by local teams of interviewers. At each site, two female and two male interviewers were selected who were IPM CRSP scientists or local extension agents familiar with the local language and area.

The research design employed a descriptive survey method and a multi-stage random sampling procedure to select tomato growers for interviewing. The research sites had been purposively selected because they were important centers of tomato production and logistically accessible. Households were randomly selected from lists of farmers from 
Kirinyaga district, Mwea division, in Kenya, and three villages in Morogoro region, Tanzania, but interviews were purposively conducted only with individuals actively engaged in tomato production. All questionnaires were completed by personal interviews. A total of 219 questionnaires were completed and used in the analysis. In Kenya, a total of 119 usable questionnaires were completed of which 20 were female and 99 were male tomato growers. In Tanzania, 100 usable questionnaires were completed of which 33 were female and 67 were male tomato growers.

The analysis examines gender and contextual differences using various measures of association and t-tests of mean differences to assess grouped and continuous data.

\section{Findings}

\subsection{Sample Characteristics}

The survey respondents were 76 percent male and 24 percent female. Although "head-of-household" was not used as a screening question, sampled farmers were asked if they were knowledgeable and actively engaged in tomato production and this may have served to lower the number of female respondents. In terms of contextual distribution, slightly over half (54.5 percent) of the respondents were from the Mwea site and 45.5 percent from the Morogoro site.

\subsection{Gender and Contextual Differences: Socio-demographic Characteristics and Production Resources}

A t-test of mean differences was used to assess the influence of gender and context on socio-demographic characteristics and production resources (Table 1 \&2). There were no significant differences between male and female farmers and site contexts on age, household size, and farm size. Significant mean differences between male and female farmers and site contexts were found for years of education and land in tomato production. Male farmers had more years of education $(\mathrm{M}=8.00, \mathrm{SD}=2.93)$ than female farmers $(\mathrm{M}=6.58, \mathrm{SD}=2.97)$, $\mathrm{t}(217)=3.052, \mathrm{p}<0.01$. Contextually, farmers in Mwea had more years of education $(\mathrm{M}=8.44, \mathrm{SD}=3.46)$ than farmers in Morogoro $(\mathrm{M}=6.71, \mathrm{SD}=1.94), \mathrm{t}(217)=4.636, \mathrm{p}<0.001$. To confirm that the observed significant contextual differences in levels of education were not related to gender, a within-context test of mean gender differences in educational levels was conducted. There were no significant differences in education levels (years of education) between male and female farmers at the Morogoro site, indicating that gender differences in educational levels vary according to context.

In terms of differences in access to production resources, a test of mean differences revealed that male farmers reported significantly more land in tomato production $(\mathrm{M}=1.29, \mathrm{SD}=1.21)$ than female farmers $(\mathrm{M}=0.771, \mathrm{SD}=0.566), \mathrm{t}(217)=4.267, \mathrm{p}<0.001$. Contextually, farmers at the Morogoro site reported significantly more acres in tomato production $(\mathrm{M}=1.41, \mathrm{SD}=1.12)$ compared to farmers at the Mwea site $(\mathrm{M}=0.963, \mathrm{SD}=1.07), \mathrm{t}(217)=-3.004, \mathrm{p}<0.001$. 
Table 1. Socio-demographic and production characteristics by gender

\begin{tabular}{lllll}
\hline Characteristic & $\begin{array}{l}\text { Male } \\
(\mathrm{N}=166)\end{array}$ & $\begin{array}{l}\text { Female } \\
(\mathrm{N}=53)\end{array}$ & df & $\mathrm{T}$ \\
\hline Age & $36.99(11.42)$ & $36.03(10.64)$ & 217 & 0.539 \\
Education & $8.00(2.93)$ & $6.58(2.97)$ & 217 & $3.052 * *$ \\
Household size & $4.49(2.02)$ & $4.65(1.70)$ & 217 & -0.514 \\
Farm size & $3.63(3.96)$ & $2.83(2.17)$ & 217 & 1.705 \\
Land under tomato & $1.29(1.21)$ & $0.771(.566)$ & 217 & $4.267 * * *$ \\
production & & & $* * * \mathrm{p}<0.001$ \\
\hline $\begin{array}{l}\text { Note: values in parenthesis are standard deviations } \\
* \mathrm{p}<0.05\end{array}$ & $* \mathrm{p}^{2}<0.01$ & & \\
\hline
\end{tabular}

Table 2. Socio-demographic and production characteristics by context

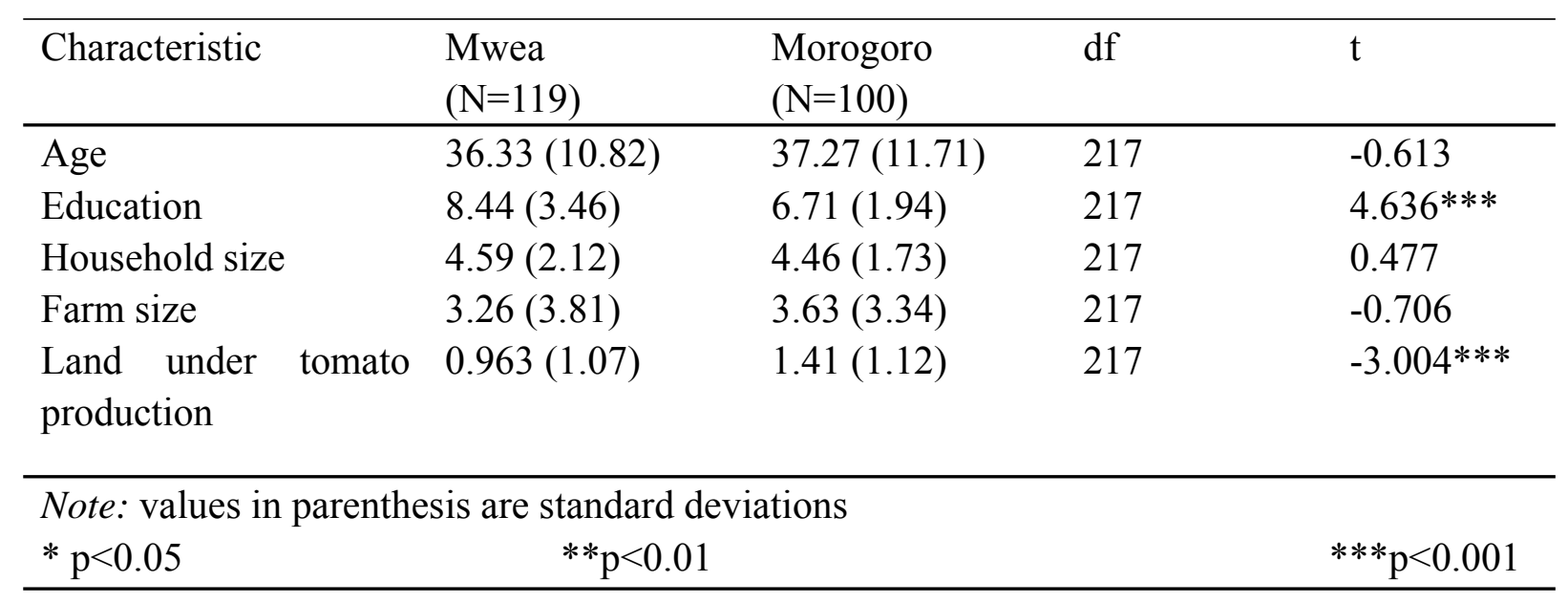

An examination of the within-context gender differences in access to land resources indicates that in both contexts, Mwea and Morogoro, there were significant gender differences in the amount of land allocated to tomato production, with female farmers having less land, on average, under tomato cultivation than male farmers. These within-context results are consistent with the gender differences found across context (Table 1), and suggest that regardless of context, gender influences the resources that farmers are able to dedicate to a particular crop.

\subsection{Gender and Contextual Differences in Farm-level Decision-making}

Farm-level decision-making in this study refers to production-related activities including use of pesticides, use of organic or inorganic fertilizers, pesticide application strategies, pesticide safety procedures, and record keeping practices. A chi-square test was performed to examine gender and contextual differences in farm-level decision-making. 


\subsubsection{Pesticides}

All farmers at both sites reported the prevalent use of chemical pesticides (16-24 applications per season) as their main form of pest management. At both sites, male farmers were more likely to apply pesticides.

\subsubsection{Inorganic Fertilizers}

There were no significant gender or contextual differences in inorganic fertilizer use, with over 90 percent of the farmers, at both sites, indicating that they were using inorganic fertilizers.

\subsubsection{Organic Fertilizers}

Gender and contextual differences in the use of organic fertilizers indicated that the decision to use organic fertilizers was more related to context than gender. Farmers at the Mwea site were more likely to use organic fertilizers, $\left.\mathrm{X}^{2}(1, \mathrm{~N}=218)=50.294, \mathrm{p}<0.001\right)$, than farmers at the Morogoro site. Use of organic fertilizers at the Morogoro site was negligible and only one farmer reported using manure for tomato production. Conversely, in Mwea, nearly 42 percent of the farmers reported using manure for tomato production and no significant gender differences were detected.

\subsubsection{Pesticide Application Strategies}

Farmers were asked the decision strategy they used to determine when they would use pesticides. Pesticide application strategies were found to be more related to context than gender (Table 3). Farmers at the Mwea site were significantly more likely to report using pesticides after field scouting, $\mathrm{X}^{2}(1, \mathrm{~N}=202)=34.261, \mathrm{p}<0.001$, or having observed pests in the field, $X^{2}(1, N=207)=25.057, p<0.001$. On the other hand, farmers at the Morogoro site were significantly more likely to report that they applied pesticides at regular intervals during the growing season, $X^{2}(1, N=217)=7.820, p<0.01$. Significant gender differences were only found for application of pesticides after field scouting, $X^{2}(1, N=.202)=8.149, p<0.01$, with male farmers being significantly more likely to report using the field scouting strategy.

\subsubsection{Pesticide Safety Procedures}

Significant contextual differences were found for all pesticide safety procedures, which included reading pesticide labels before applying pesticides, wearing protective clothing, observing a 12-hour waiting period, observing pre-harvest waiting periods, and pesticide storage (Table 4). Farmers in Mwea were significantly more likely to follow most safety procedures including: reading labels before applying pesticides, $X^{2}(1, N=218)=7.773$, $\mathrm{p}<0.01$; observing a 12-hour waiting period before entering a plot, $\mathrm{X}^{2}(1, \mathrm{~N}=218)=10.090$, $\mathrm{p}<0.01$; observing pre-harvest waiting periods, $\mathrm{X}^{2}(1, \mathrm{~N}=218)=14.887, \mathrm{p}<0.001$; and wearing protective clothing, $\mathrm{X}^{2}(1, \mathrm{~N}=218)=44.716, \mathrm{p}<0.001$. However, storing pesticides away from children, was practiced more often by farmers at the Morogoro site, $X^{2}(1,217)=$ 9.857, $\mathrm{p}<0.01$.

Gender differences were found for some pesticide safety procedures. Male farmers were more 
likely to read pesticide labels, $\mathrm{X} 2(1, \mathrm{~N}=218)=11.149, \mathrm{p}<0.01$, and observe a 12-hour waiting period before entering fields, $\mathrm{X} 2(1, \mathrm{~N}=218)=5.301, \mathrm{p}<0.05$. These gender differences may be related to the earlier reported findings that male farmers at both sites were more likely to apply pesticides, and may; therefore, be more interested and aware of correct and safe usage.

Table 3. Gender and contextual differences pesticide application strategies

\section{Gender}

Context

Application

Strategies

\begin{tabular}{|c|c|c|c|c|c|c|c|c|}
\hline & Male & Female & Total & $\mathrm{X}^{2}$ & Mwea & Morogoro & Total & $\mathrm{X}^{2}$ \\
\hline \multicolumn{9}{|c|}{ Apply at regular intervals throughout season } \\
\hline Yes & $\begin{array}{l}132 \\
(80.5)\end{array}$ & $\begin{array}{l}48 \\
(90.6)\end{array}$ & 180 & 2.877 & $\begin{array}{l}91 \\
(76.5)\end{array}$ & $\begin{array}{l}89 \\
(90.8)\end{array}$ & 180 & $7.820 * *$ \\
\hline No & $\begin{array}{l}32 \\
(19.5)\end{array}$ & $\begin{array}{l}5 \\
(9.4)\end{array}$ & 37 & & $\begin{array}{l}28 \\
(23.5)\end{array}$ & $\begin{array}{l}9 \\
(9.2)\end{array}$ & 37 & \\
\hline Total & $\begin{array}{l}164 \\
(75.6)\end{array}$ & $\begin{array}{l}53 \\
(24.4)\end{array}$ & 217 & & 119 & 98 & 217 & \\
\hline \multicolumn{9}{|c|}{ Use pesticides after field scouting } \\
\hline Yes & $\begin{array}{l}51 \\
(33.3)\end{array}$ & $\begin{array}{l}6 \\
(12.2)\end{array}$ & 57 & $8.149 * *$ & $\begin{array}{l}52 \\
(43.7)\end{array}$ & $\begin{array}{l}5 \\
(6.0)\end{array}$ & 57 & $34.261 * * *$ \\
\hline No & $\begin{array}{l}102 \\
(66.7)\end{array}$ & $\begin{array}{l}43 \\
(87.8)\end{array}$ & 145 & & $\begin{array}{l}67 \\
(56.3)\end{array}$ & $\begin{array}{l}78 \\
(94.0\end{array}$ & 145 & \\
\hline Total & 153 & 49 & 202 & & 119 & 83 & 202 & \\
\hline \multicolumn{9}{|c|}{ Use pesticides when we see pests } \\
\hline Yes & $\begin{array}{l}86 \\
(54.8)\end{array}$ & $\begin{array}{l}21 \\
(42.0)\end{array}$ & 107 & 2.479 & $\begin{array}{l}80 \\
(67.2)\end{array}$ & $\begin{array}{l}27 \\
(30.7)\end{array}$ & 107 & $25.057 * * *$ \\
\hline No & $\begin{array}{l}71 \\
(45.2)\end{array}$ & $\begin{array}{l}29 \\
(58.0)\end{array}$ & 100 & & $\begin{array}{l}39 \\
(32.8)\end{array}$ & $\begin{array}{l}61 \\
(69.3)\end{array}$ & 100 & \\
\hline Total & 157 & 50 & 207 & & 119 & 88 & 207 & \\
\hline
\end{tabular}

Note: Numbers in parentheses are column percentages

$* \mathrm{p}<0.05$

$* * p<0.01$

$* * * \mathrm{p}<0.001$ 
Table 4. Gender and contextual differences in pesticide use safety procedures

\begin{tabular}{|c|c|c|c|c|c|c|c|c|}
\hline \multirow{2}{*}{$\begin{array}{l}\text { Application } \\
\text { Strategies }\end{array}$} & \multicolumn{3}{|c|}{ Gender } & \multicolumn{5}{|c|}{ Context } \\
\hline & Male & Female & Total & $\mathrm{X}^{2}$ & Mwea & Morogoro & Total & $\mathrm{X}^{2}$ \\
\hline \multicolumn{9}{|c|}{ Read labels before applying pesticides } \\
\hline Yes & $\begin{array}{l}159 \\
(96.4)\end{array}$ & $\begin{array}{l}44 \\
(83.0)\end{array}$ & 203 & $11.149 * *$ & $\begin{array}{l}116 \\
(97.5)\end{array}$ & $\begin{array}{l}87 \\
(87.9)\end{array}$ & 203 & $7.773 * *$ \\
\hline No & $\begin{array}{l}6 \\
(3.6)\end{array}$ & $\begin{array}{l}9 \\
(17.0)\end{array}$ & 15 & & $\begin{array}{l}3 \\
(2.5)\end{array}$ & $\begin{array}{l}12 \\
(12.1)\end{array}$ & 15 & \\
\hline Total & 165 & 53 & 218 & & 119 & 99 & 218 & \\
\hline \multicolumn{9}{|c|}{ Observe 12- hour waiting period before entering field } \\
\hline Yes & $\begin{array}{l}134 \\
(81.2)\end{array}$ & $\begin{array}{l}35 \\
(66.0)\end{array}$ & 169 & $5.301 *$ & $\begin{array}{l}102 \\
(85.6)\end{array}$ & $67(67.7)$ & 169 & $10.090 * *$ \\
\hline No & $\begin{array}{l}31 \\
(18.8)\end{array}$ & $\begin{array}{l}18 \\
(34.0)\end{array}$ & 49 & & $\begin{array}{l}17 \\
(14.3)\end{array}$ & $32(32.3)$ & 49 & \\
\hline Total & 165 & 53 & 218 & & 119 & 99 & 218 & \\
\hline \multicolumn{9}{|c|}{ Observe pre-harvest waiting periods } \\
\hline Yes & $\begin{array}{l}148 \\
(89.7)\end{array}$ & $\begin{array}{l}44 \\
(83)\end{array}$ & 192 & 1.703 & $\begin{array}{l}114 \\
(95.8)\end{array}$ & $\begin{array}{l}78 \\
(78.8)\end{array}$ & 192 & $14.887 * * *$ \\
\hline No & $\begin{array}{l}17 \\
(10.3)\end{array}$ & $\begin{array}{l}9 \\
(17)\end{array}$ & 26 & & $\begin{array}{l}5 \\
(4.2)\end{array}$ & $\begin{array}{l}21 \\
(21.2)\end{array}$ & 26 & \\
\hline Total & 165 & 53 & 218 & & 119 & 99 & 218 & \\
\hline \multicolumn{9}{|c|}{ Store pesticides out of the reach of children } \\
\hline Yes & $\begin{array}{l}153 \\
(95.3)\end{array}$ & $\begin{array}{l}49 \\
(92.5)\end{array}$ & 202 & 0.044 & $\begin{array}{l}104 \\
(88.1)\end{array}$ & $\begin{array}{l}98 \\
(99.0)\end{array}$ & 202 & $9.857 * *$ \\
\hline No & $\begin{array}{l}11 \\
(6.7)\end{array}$ & $\begin{array}{l}4 \\
(7.5)\end{array}$ & 15 & & $\begin{array}{l}14 \\
(11.9)\end{array}$ & $\begin{array}{l}1 \\
(1.0)\end{array}$ & 15 & \\
\hline Total & 164 & 53 & 217 & & 118 & 99 & 217 & \\
\hline \multicolumn{9}{|c|}{ Wear protective clothing } \\
\hline Yes & $\begin{array}{l}95 \\
(57.6)\end{array}$ & $\begin{array}{l}27 \\
(50.9)\end{array}$ & 122 & 0.716 & $\begin{array}{l}91 \\
(76.5)\end{array}$ & $\begin{array}{l}31 \\
(31.3)\end{array}$ & 122 & $44.716^{* * *}$ \\
\hline No & $\begin{array}{l}70 \\
(42.4)\end{array}$ & $\begin{array}{l}26 \\
(49.1)\end{array}$ & 96 & & $\begin{array}{l}28 \\
(23.5)\end{array}$ & $\begin{array}{l}68 \\
(68.7)\end{array}$ & 96 & \\
\hline Total & 165 & 53 & 218 & & 119 & 99 & 218 & \\
\hline $\begin{array}{l}\text { Note: Num } \\
* \mathrm{p}<0.05\end{array}$ & $\mathrm{~s}$ in par & entheses & $\begin{array}{l}\text { e colur } \\
* * p<0\end{array}$ & in percenta & & & & $* * \mathrm{p}<0.001$ \\
\hline
\end{tabular}




\subsubsection{Pesticide Use Record Keeping}

There were significant gender differences in pesticide-related record keeping (Table 5). Male farmers were more likely to keep a record of the application location, $\mathrm{X}^{2}(1, \mathrm{~N}=219)=4.525$, $\mathrm{p}<0.05$; application dates, $\mathrm{X} 2(1, \mathrm{~N}=219)=4.010, \mathrm{p}<0.05$; and the pesticide product name, $\mathrm{X}^{2}$ $(1, \mathrm{~N}=219)=9.407, \mathrm{p}<0.01$. As in the case of pesticide safety procedures, this finding perhaps reflects that male farmers were more likely to apply pesticides. Contextually, no significant differences were noted except for-farmers at the Mwea site, who were significantly more likely to report recording the pesticide product trade name compared to farmers at the Morogoro site, X2 $(1, \mathrm{~N}=219)=10.552, \mathrm{p}<0.01$.

Table 5. Gender and contextual differences in pesticide use record keeping

$$
\text { Gender }
$$

Context

\section{Record}

Keeping

\begin{tabular}{|c|c|c|c|c|c|c|c|c|}
\hline & Male & Female & Total & $\mathrm{X}^{2}$ & Mwea & Morogoro & Total & $X^{2}$ \\
\hline \multicolumn{9}{|c|}{ Keep records on application location } \\
\hline $\overrightarrow{\text { Yes }}$ & $\begin{array}{l}71 \\
(42.8)\end{array}$ & $\begin{array}{l}14 \\
(26.4)\end{array}$ & 85 & $4.525^{*}$ & $\begin{array}{l}44 \\
(37.0\end{array}$ & $\begin{array}{l}41 \\
(41.0)\end{array}$ & 85 & 0.371 \\
\hline No & $\begin{array}{l}95 \\
(57.2)\end{array}$ & $\begin{array}{l}39 \\
(73.6)\end{array}$ & 134 & & $\begin{array}{l}75 \\
(56.0)\end{array}$ & $\begin{array}{l}59 \\
(59.0)\end{array}$ & 134 & \\
\hline Total & 166 & 53 & 219 & & 119 & 100 & 219 & \\
\hline \multicolumn{9}{|c|}{ Keep records on date of application } \\
\hline Yes & $\begin{array}{l}76 \\
(45.8)\end{array}$ & $\begin{array}{l}16 \\
(30.2)\end{array}$ & 92 & $4.010 *$ & $\begin{array}{l}52 \\
(43.7)\end{array}$ & $\begin{array}{l}40 \\
(43.5)\end{array}$ & 92 & 0.305 \\
\hline No & $\begin{array}{l}90 \\
(54.2)\end{array}$ & $\begin{array}{l}37 \\
(69.8)\end{array}$ & 127 & & $\begin{array}{l}67 \\
(56.3)\end{array}$ & $\begin{array}{l}60 \\
(47.2)\end{array}$ & 127 & \\
\hline Total & 166 & 53 & 219 & & 119 & 100 & 219 & \\
\hline \multicolumn{9}{|c|}{ Keep records on pesticide product trade name } \\
\hline $\overrightarrow{\text { Yes }}$ & $\begin{array}{l}70 \\
(42.2)\end{array}$ & $\begin{array}{l}10 \\
(18.9)\end{array}$ & 80 & $9.407 * *$ & $\begin{array}{l}55 \\
(46.2)\end{array}$ & $\begin{array}{l}25 \\
(25.0)\end{array}$ & 80 & $10.552 * *$ \\
\hline No & $\begin{array}{l}96 \\
(57.8)\end{array}$ & $\begin{array}{l}43 \\
(81.1)\end{array}$ & 139 & & $\begin{array}{l}64 \\
(53.8)\end{array}$ & $\begin{array}{l}75 \\
(75.0)\end{array}$ & 139 & \\
\hline Total & 166 & 53 & 219 & & 119 & 100 & 219 & \\
\hline
\end{tabular}

Note: Numbers in parentheses are column percentages

$* \mathrm{p}<0.05$

$* * \mathrm{p}<0.01$

$* * * \mathrm{p}<0.001$ 


\subsection{Gender and Contextual Differences in Tomato Crop Output and End-Use Decisions}

A key objective of IPM strategies is food security; ensuring that harvests adequately nourish the farmers and their families (International Institute of Tropical Agriculture (IITA), 2008). Crop output is therefore an important feature of any assessment of IPM strategies. Beyond food security, IPM also seeks to enhance farmers capacity to grow and sell their product, whether in the local or export markets, a strategy that is increasingly recognized as a key ingredient in alleviating poverty in developing countries (IITA, 2008). In line with these objectives, this section focuses on gender and contextual differences in crop output and marketing decisions; information that could be useful in targeted IPM efforts.

\subsubsection{Crop Output}

A t-test of mean differences conducted to compare the output levels and end use of the tomato crop revealed significant gender and contextual differences (Table 6). Male farmers, $(\mathrm{M}=$ 156.57, $\mathrm{SD}=189.51)$ reported harvesting significantly more boxes of the tomato crop compared to female farmers $(M=77.43, S D=60.36), t(214)=4.644, p<0.001$. These significant differences may derive from the earlier observed significant gender differences in the land under tomato production. Contextually, the mean number of boxes harvested at the Morogoro site $(M=173.45, S D=167.08)$ were significantly higher compared to the mean number of boxes harvested at the Mwea site $(\mathrm{M}=107.36, \mathrm{SD}=169.68), \mathrm{t}(213)=2.870, \mathrm{p}<0.05$; a finding that may be attributed to the earlier finding of significant differences in the amount of land dedicated to tomato production in the two regions.

\subsubsection{Crop Marketing Decisions}

In terms of the total number of boxes sold, the results revealed that on average, male farmers $(\mathrm{M}=153.49, \mathrm{SD}=188.27)$ sold significantly more boxes of tomatoes than female farmers $(\mathrm{M}=75.33, \mathrm{SD}=60.88), \mathrm{t}(214)=4.599, \mathrm{p}<0.001$. Contextually, farmers at the Morogoro site $(\mathrm{M}=168.95, \mathrm{SD}=165.05)$ sold significantly more boxes of tomatoes than farmers at the Mwea site $(\mathrm{M}=105.76, \mathrm{SD}=168.95), \mathrm{t}(214)=2.771, \mathrm{p}<0.05$.

A more insightful analysis involved examining the presence of gender and contextual differences in the ratio of crop sold to the crop harvested. The results indicate that farmers marketed most of the product and no significant gender or contextual differences were found in the proportion of tomato produce marketed (Table 6). Moreover, the finding of no relationship between gender and the proportion of crop sold was maintained in both IPM sites. 
Table 6. Gender and contextual differences in crop output and end use decisions

\begin{tabular}{|c|c|c|c|c|c|c|c|c|}
\hline \multirow{2}{*}{ Output/Marketing } & \multicolumn{2}{|c|}{ Gender } & \multicolumn{6}{|c|}{ Context } \\
\hline & $\begin{array}{l}\text { Male } \\
\mathrm{N}=164\end{array}$ & $\begin{array}{l}\text { Female } \\
\mathrm{N}=52\end{array}$ & $\mathrm{df}$ & $\mathrm{t}$ & $\begin{array}{l}\text { Mwea } \\
\mathrm{N}=116\end{array}$ & $\begin{array}{l}\text { Morogoro } \\
\mathrm{N}=99\end{array}$ & df & $\mathrm{t}$ \\
\hline $\begin{array}{l}\text { Crop Harvested } \\
\text { (mean number of } \\
\text { boxes) }\end{array}$ & $\begin{array}{l}156.57 \\
(189.51)\end{array}$ & $\begin{array}{l}77.43 \\
(60.36)\end{array}$ & 214 & $4.644^{* * *}$ & $\begin{array}{l}107.36 \\
(169.68)\end{array}$ & $\begin{array}{l}173.45 \\
(167.08)\end{array}$ & 213 & $2.870^{*}$ \\
\hline $\begin{array}{l}\text { Crop Sold (mean } \\
\text { number of boxes) }\end{array}$ & $\begin{array}{l}153.49 \\
(188.27) \\
\end{array}$ & $\begin{array}{l}75.33 \\
(60.88) \\
\end{array}$ & 214 & $4.599 * * *$ & $\begin{array}{l}105.76 \\
(169.23) \\
\end{array}$ & $\begin{array}{l}168.95 \\
(165.05) \\
\end{array}$ & 213 & $2.771^{*}$ \\
\hline $\begin{array}{l}\text { Ratio of crop sold } \\
\text { to crop harvested }\end{array}$ & $\begin{array}{l}0.980 \\
(0.086)\end{array}$ & $\begin{array}{l}0.975 \\
(0.117)\end{array}$ & 214 & 0.367 & $\begin{array}{l}0.982 \\
(0.091)\end{array}$ & $\begin{array}{l}0.975 \\
(0.096)\end{array}$ & 213 & 0.457 \\
\hline
\end{tabular}

Note: values in parenthesis are standard deviations

$* \mathrm{p}<0.05 \quad * * \mathrm{p}<0.01 \quad * * * \mathrm{p}<0.001$

\subsection{Gender and Contextual Differences in Access to Production Information}

There is broad consensus about the positive relationship between technology adoption and access to production information, particularly through extension and farmer-field schools (Dethier \& Effenberger, 2011; Gautam, 2000; Kirinya et al., 2013; Quisumbing \& Pandofelli, 2009; Saito et al., 1994). According to Gautam (2000) the adoption or non-adoption decision process is a reflection in part of the quantity and relevance of the extension service. An investigation of the extent to which farmers in these two sites have access to production information is, therefore, key, in light of the study's assessment of farm-level decision making.

A chi-square test was used to assess differences in gender and contextual access to production information (Table 7). Most farmers, in both contexts reported other tomato farmers as their primary source of tomato production information. However, male farmers were significantly more likely to report other farmers as their primary source of production information, $X^{2}(1$, $\mathrm{N}=219)=4.010, \mathrm{p}<0.05$. In terms of extension as a source of information, male farmers were significantly more likely to report using extension agents as their primary source of information, $\mathrm{X}^{2}(1, \mathrm{~N}=219)=3.393, \mathrm{p}<0.05$. Contextually, significant differences were found for extension and other sources, which included brochures and workshops, as the primary source of production information. Farmers at the Morogoro site, were significantly more likely to report using extension as their primary source of production information

$\mathrm{X}^{2}(1, \mathrm{~N}=219)=4.315, \mathrm{p}<0.05$, and farmers at the Mwea site, were significantly more likely to report using other sources of information, which included brochures and workshops, $\mathrm{X}^{2}(1, \mathrm{~N}=212)=13.133 \mathrm{p}<0.001$. 
Table 7. Gender and contextual differences in access to production information

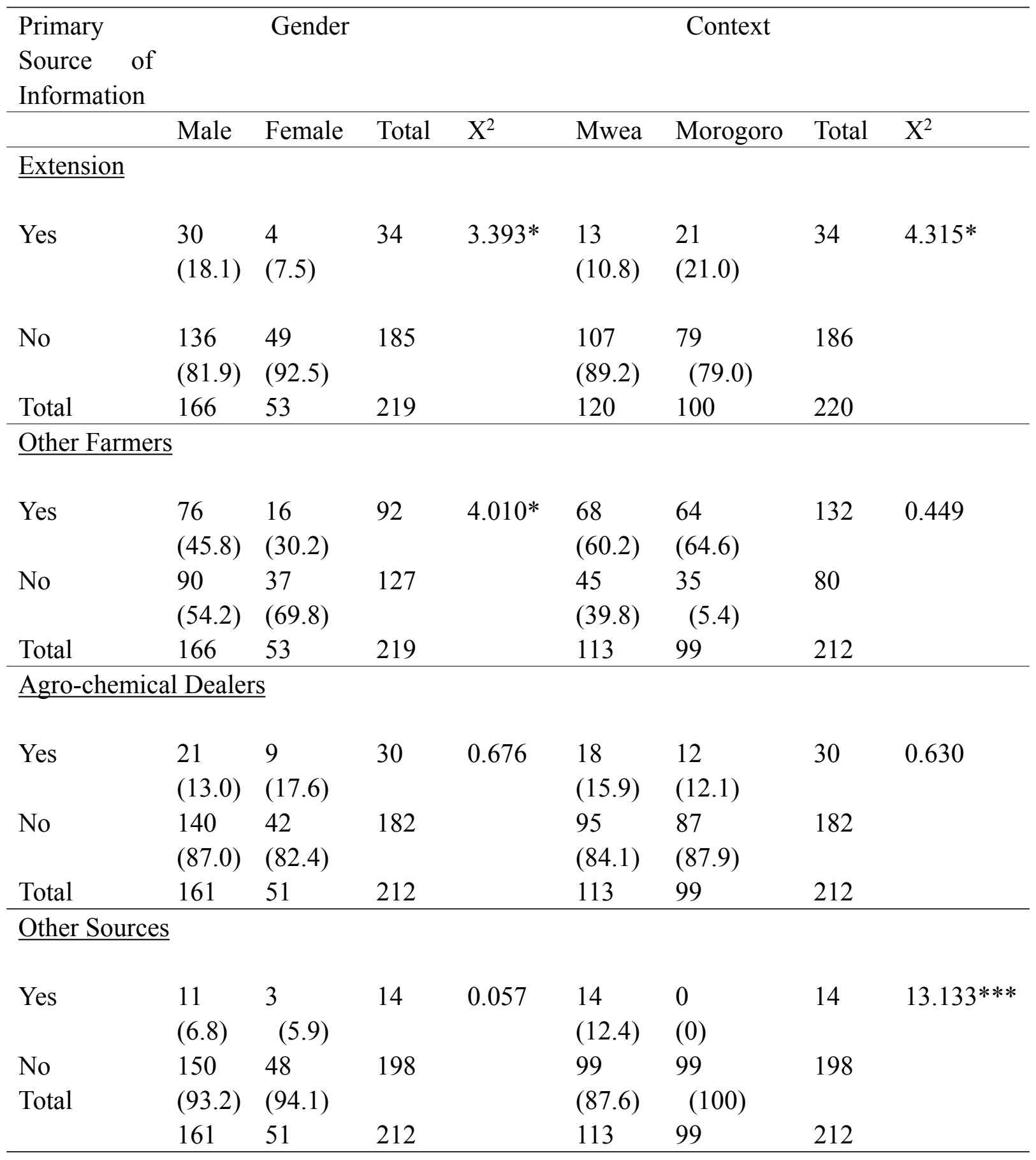

Note: Numbers in parentheses are column percentages

$* \mathrm{p}<0.05$ 
Table 8. Gender and contextual differences in IPM and pesticide use training

IPM/Other Gender Context

Training

\begin{tabular}{|c|c|c|c|c|c|c|c|c|}
\hline & Male & Female & Total & $\mathrm{X}^{2}$ & Mwea & Morogoro & Total & $\mathrm{X}^{2}$ \\
\hline \multicolumn{9}{|c|}{ Received IPM Training } \\
\hline Yes & $\begin{array}{c}8 \\
(4.9)\end{array}$ & $\begin{array}{c}3 \\
(5.7)\end{array}$ & 11 & 0.051 & $\begin{array}{c}11 \\
(9.4)\end{array}$ & $\begin{array}{c}0 \\
(0)\end{array}$ & 11 & $9.904 * *$ \\
\hline No & $\begin{array}{c}156 \\
(95.1)\end{array}$ & $\begin{array}{c}50 \\
(94.3)\end{array}$ & 206 & & $\begin{array}{c}106 \\
(90.6)\end{array}$ & $\begin{array}{l}100 \\
(100)\end{array}$ & 206 & \\
\hline Total & 164 & 53 & 217 & & 117 & 100 & 217 & \\
\hline \multicolumn{9}{|c|}{$\underline{\text { Received Training on Pesticide Application }}$} \\
\hline Yes & $\begin{array}{c}25 \\
(15.1)\end{array}$ & $\begin{array}{c}3 \\
(5.7)\end{array}$ & 28 & 3.183 & $\begin{array}{c}27 \\
(22.7)\end{array}$ & $\begin{array}{c}1 \\
(1.0)\end{array}$ & 28 & $22.924 * * *$ \\
\hline No & $\begin{array}{c}141 \\
(84.9)\end{array}$ & $\begin{array}{c}50 \\
(94.3)\end{array}$ & 191 & & $\begin{array}{c}92 \\
(77.3)\end{array}$ & $\begin{array}{l}99 \\
(99)\end{array}$ & 191 & \\
\hline Total & 166 & 53 & 219 & & 119 & 100 & 219 & \\
\hline \multicolumn{9}{|c|}{ Received Training on Pesticide Safety } \\
\hline Yes & $\begin{array}{c}26 \\
(15.7)\end{array}$ & $\begin{array}{c}2 \\
(3.8)\end{array}$ & 28 & $5.093 *$ & $\begin{array}{c}27 \\
(22.7)\end{array}$ & $\begin{array}{c}1 \\
(1.0)\end{array}$ & 28 & $22.924 * * *$ \\
\hline No & $\begin{array}{c}140 \\
(84.3)\end{array}$ & $\begin{array}{c}51 \\
(96.2)\end{array}$ & 191 & & $\begin{array}{c}92 \\
(77.3)\end{array}$ & $\begin{array}{c}99 \\
(99)\end{array}$ & 191 & \\
\hline Total & 166 & 53 & 219 & & 119 & 100 & 219 & \\
\hline \multicolumn{9}{|c|}{$\underline{\text { Received Training on Insect Identification }}$} \\
\hline Yes & $\begin{array}{c}18 \\
(10.8)\end{array}$ & $\begin{array}{l}0 \\
(0)\end{array}$ & 18 & $6.262 *$ & $\begin{array}{c}17 \\
(14.3)\end{array}$ & $\begin{array}{c}1 \\
(1.0)\end{array}$ & & $12.714 * * *$ \\
\hline No & $\begin{array}{c}148 \\
(89.2)\end{array}$ & $\begin{array}{c}53 \\
(100)\end{array}$ & 201 & & $\begin{array}{c}102 \\
(85.7)\end{array}$ & $\begin{array}{l}99 \\
(99)\end{array}$ & & \\
\hline Total & 166 & 53 & 219 & & 119 & 100 & 219 & \\
\hline
\end{tabular}

Received Training on Disease Identification

\begin{tabular}{|c|c|c|c|c|c|c|c|}
\hline Yes & $\begin{array}{c}22 \\
(13.3)\end{array}$ & $\begin{array}{c}0 \\
(0)\end{array}$ & 22 & $7.809 * *$ & $\begin{array}{c}21 \\
(17.6)\end{array}$ & $\begin{array}{c}1 \\
(1.0)\end{array}$ & 22 \\
\hline No & $\begin{array}{c}144 \\
(86.7)\end{array}$ & $\begin{array}{c}53 \\
(100)\end{array}$ & 197 & & $\begin{array}{c}98 \\
(82.4)\end{array}$ & $\begin{array}{l}99 \\
(99)\end{array}$ & 197 \\
\hline Total & 166 & 53 & 219 & & 119 & 100 & 219 \\
\hline
\end{tabular}

Received Training on Tomato Crop Quality Aspects

\begin{tabular}{lcccccccc} 
Yes & 14 & 1 & 15 & 2.672 & 15 & 0 & 15 & \\
& $(8.5)$ & $(1.9)$ & & & $(12.9)$ & $(0)$ & & \\
No & 150 & 51 & 201 & & 101 & 100 & 201 & \\
& $(91.5)$ & $(98.1)$ & & & $(87.1)$ & $(100)$ & & \\
Total & 164 & 52 & 216 & & 116 & 100 & 216 & $13.896^{* * *}$ \\
\hline
\end{tabular}

Note: Numbers in parentheses are column percentages

$* \mathrm{p}<0.05$

$* * \mathrm{p}<0.01$

$* * * \mathrm{p}<0.001$ 
An analysis was also conducted to examine gender and contextual differences in access to IPM training as well as other forms of training on pesticide use, insect and disease identification, and quality aspects of the tomato crop (Table 8). In general, there was low access to IPM training but there was a slight but significant difference between farmers in Morogoro and Mwea, with farmers in Mwea being more likely to have received some IPM training X2 $(1, \mathrm{~N}=217)=9.904, \mathrm{p}<0.001$. Significant gender differences were found for training on pesticide safety, insect identification, and diseases identification. Compared to female farmers, male farmers reported a significantly higher likelihood of having access to information on pesticide safety, $\mathrm{X}^{2}(1, \mathrm{~N}=219)=5.093, \mathrm{p}<0.05$; insect identification, $\mathrm{X}^{2}$ $(\mathrm{N}=219)=6.262, \mathrm{p}<0.05$; and disease identification, $\mathrm{X}^{2}(1, \mathrm{~N}=219)=7.809, \mathrm{p}<0.01$. Contextually, significant differences were found for all aspects of tomato production-related training. Compared to farmers at the Morogoro site, farmers at the Mwea site were significantly more likely to report having had access to training on pesticide application, X2 $(1, \mathrm{~N}=219)=22.924$; training on pesticide safety, $\mathrm{X} 2(1, \mathrm{~N}=219)=22.924, \mathrm{p}<0.001$; training on insect, $\mathrm{X} 2(1, \mathrm{~N}=219)=12.714, \mathrm{p}<0.001$; and disease identification, $\mathrm{X} 2(1, \mathrm{~N}=219)=$ $16.664, \mathrm{p}<0.001$; and training on quality aspects of the tomato crop, $\mathrm{X} 2(1, \mathrm{~N}=219)=13.896$, $\mathrm{p}<0.001$.

\section{Discussion and Study Implications}

The purpose of the study was to compare and contrast gender and contextual influences on tomato production, farm-level decision-making and marketing practices, and to use this information to improve IPM program design and delivery with tomato growers at participatory research sites in Kenya and Tanzania. The study started by assessing gender differences in socio-demographic factors. It is well documented in the gender and agricultural development literature that women in Africa, generally have lower levels of education than men (Blackden et al., 2005; Due \& Gladwin, 1991; Quisumbing \& Pandofelli, 2009). In this study, when gender differences in education were examined, without taking the context into account, male farmers were found to have significantly higher levels of education than female farmers. However an examination of the within context gender differences in education did not reveal significant differences between male and female farmers at the Morogoro site. These results suggest the need to always consider contextual differences to design appropriate programmatic interventions.

An analysis of the production characteristics indicates that regardless of context, there were significant gender differences in the amount of land under tomato production, with male farmers having more land on average under tomato production. These findings are consistent with the gender and agriculture literature that underscores African women's limited access to production-related resources (Boserup 1970; Davison, 1988; FAO, 2011; Lastarria-Cornhiel, 1997; Quisumbing \& Pandofelli, 2009; Quisumbing et al., 2014). This may also be attributable to women being more likely to use the land under their control to satisfy household food production needs, leaving less land available for commercial crop production (Blackden et al., 2005; Kennedy \& Peters, 1993; Quisumbing \& Pandofelli, 2009).

There were also contextual and gender similarities in tomato production and marketing. Both 
male and female farmers at both sites reported the prevalent use of synthetic pesticides, inorganic fertilizers and producing tomato for cash markets. This suggests that the gender-specific nature of traditional African farming may be transitioning particularly for higher value marketed crops like tomato. The literature on gender and agricultural development has long posited a traditional male/cash crop, female/food crop dichotomy, and that women have limited control over crops with an exchange value (Boserup, 1970; Davison, 1988; Sachs, 1996; Spring, 2000). An examination of the ratio of crop harvested to crop sold (proportion marketed) did not reveal any gender or contextual differences, suggesting that for both male and female farmers, tomato is viewed as a cash crop grown primarily for market. That there were no gender differences in the proportion of crop production marketed indicates that women farmers were able to maintain control and make decisions pertaining to the production and end-use of the crop, and that the traditional cropping dichotomy many not apply to higher value marketed crops, like tomato.

Significant gender differences were found in a number of farm-level decision making components including all aspects of pesticide-related record keeping; some pesticide safety procedures (reading labels before applying pesticides and observing a 12-hour waiting period before entering fields); and using pesticides after field scouting. Additionally, significant gender differences were found in access to training on pesticide safety and disease and insect identification. These findings imply the importance of acknowledging and incorporating gender differences into IPM program design and delivery by ensuring that women farmers have access to the full range of training and knowledge transfer opportunities (Erbaugh et al. 2010). This is particularly important considering women's limited access to extension services as exemplified in the findings indicating that female farmers were significantly less likely to use extension as their first source of information.

While we cannot ignore the significance of gender, in this study contextual differences were prevalent, suggesting that "one-size does not fit all" and that planned interventions need to be tailored to specific contexts (Erbaugh et al., 2010). Male farmers harvested and sold more tomatoes than female farmers, and farmers in Morogoro harvested and sold more than farmers at Mwea. Male farmers and those in Mwea were more likely than female farmers and those in Morogoro to be using field scouting and pesticide safety practices. Other contextual differences were found for marketing outlets and use of organic fertilizers. Thus a final lesson is that agricultural development practitioners need to be cautious about overgeneralizing the effects of gender across contexts and that these programs need to reflect the specific contexts in which gender relations unfold.

\section{References}

Blackden, M., Canagarajah, S., Klasen, S., \& Lawson, D. (2005). Gender and growth in sub-Saharan Africa: Evidence and issues. Washington, D.C: World Bank.

Boserup, E. (1970). Woman's role in economic development. London: Earthscan Publications

Davison, J. (1988). Land and women's agriculture: The context. In J. Davison (Eds.), Women and land: The African experience (pp. 1-32). Boulder: Westview Press. 
Doss, C. R. (2001). Designing agricultural technology for African women farmers: Lessons from 25 years of experience. World Development, 29(12), 2075-2092. http://dx.doi.org/10.1016/S0305-750X(01)00088-2

Due, J. M., \& Gladwin, C. H. (1991). Impacts of structural adjustment programs on African women farmers and female-headed households. American Journal of Agricultural Economics, 73(5), 1431-1439. http://dx.doi.org/10.2307/1242398

Erbaugh, J. M., Donnermeyer, J., Amujal, M., \& Kyamanywa, S. (2003). " The role of women in pest management decision-making in Eastern Uganda." Journal of International Agricultural and Extension http://dx.doi.org/10.5191/jiaee.2003.10309

Erbaugh, J. M., Wairimu,E., Waiganjo, M., \& Sibuga, K. (2010). Implications of gender and context on the design of IPM programs for tomato growers in East Africa. Journal of International Agricultural and Extension Education, 17(2), 55.

Food and Agricultural Organization (FAO). (2011). State of food and agriculture, 2010 -2011. A Report of the Food and Agricultural Organization of the United Nations (FAO)

Hamilton, S. (2000). The myth of the masculine market: Gender and agricultural commercialization in the Ecuadorean Andes. In A. Spring (Ed.), Women farmers and commercial ventures: Increasing food security in developing countries (pp. 65-88). Boulder, CO: Lynne Rienner Publishers.

Kennedy, E., \& Peters, P. (1993). Household food Security and child nutrition: The interaction of income and gender of household head. World Development, 20(8), 1077-1085. http://dx.doi.org/10.1016/0305-750X(92)90001-C

Kirinya, J., Taylor, D., Kyamanywa, S., Karungi, J., Erbaugh, J. M., \& Bonabana-Wabbi, J. (2013). Adoption of integrated pest management (IPM) technologies in Uganda: Review of economic studies. International Journal of Advanced Research, 1(6), 401-420.

Lastarria-Cornhiel, S. (1997). Impact of privatization on gender and property rights in Africa. World Development 25(8), 1317-1333. http://dx.doi.org/10.1016/S0305-750X(97)00030-2

Meinzen-Dick, R., Quisumbing, A., Behrman, J., Biermayr-Jenzano, P., Wilde, V., Noordeloos, M., Ragasa, C \& Beintema, N. (2011). Engendering agricultural research, development and extension. IFPRI Research Monograph. Washington, D.C: International Food Policy Research Institute (IFPRI).

Paris, T. R., Singh, A., \& Luis, J. (2001). Listening to male and female farmers in rice varietal selection: A case in Eastern India. In an Exchange Experience from South and Southeast Asia. Proceedings of the International Symposium on Participatory Plant Breeding and Participatory Plant Genetic Enhancement, Pokhara, Nepal, May 1-5, 2000.

Quisumbing, A. R., \& Pandolfelli, L. (2009). Promising Approaches to Address the Needs of Poor Female Farmers: Resources, Constraints and Interventions." IFPRI Discussion Papers. Washington, DC: International Food Policy Research Institute (IFPRI). 


\section{Macrothink}

Quisumbing, A. R., Meinzen-Dick, R. A., Raney, T. L., Croppenstedt, A., Behrman, J., \& Peterman, A. (2014). Gender in agriculture: Closing the gender gap. IFPRI Issue Brief 84. Washington D.C.: International Food Policy Research Institute (IFPRI). http://dx.doi.org/10.1007/978-94-017-8616-4

Quisumbing, A. (1996). "Male-Female Differences in Agricultural Productivity." World Development, 24, 1579-1595. http://dx.doi.org/10.1016/0305-750X(96)00059-9

Roos, D. L., \& Gladwin, C. H. (2000). The differential effects of capitalism and patriarchy on women farmers' access to markets in Cameroon. In A. Spring (Ed.), Women farmers and commercial ventures: Increasing food security in developing countries (pp. 41-64). Boulder, CO: Lynne Rienner Publishers.

Sachs, C. (1996). Gendered Fields: Rural Women, Agriculture and Environment. Boulder, CO: Westview.

Saito, K., Spurling, D., \& Mekonnen, H. (1994). Raising the Productivity of Women Farmers in Sub-Saharan Africa. World Bank Discussion Paper No. 269. Washington, DC: World Bank. http://dx.doi.org/10.1596/0-8213-2749-6

Sibuga, K. P., Maerere, A. P., Mwajombe, K. K., Kovach, J., \& Erbaugh, M. (2006). Baseline of Survey of Tomato (Lycopersicon esculentum Mill.) Production in Mvomero District, Morogoro Region in Tanzania. IPM CRSP Project Report.

Spring, A. (2000). Agricultural commercialization and women farmers in Kenya. In A. Spring (Ed.), Women farmers and commercial ventures: Increasing food security in developing countries (pp. 317-342). Boulder, CO: Lynne Rienner Publishers.

Stone, M. P., \& Stone, G. D. (2000). Kofyar women who get ahead: Incentives for agricultural commercialization in Nigeria. In A. Spring (Ed.), Women farmers and commercial ventures: Increasing food security in developing countries (pp. 153-170). Boulder, CO: Lynne Rienner Publishers.

Waiganjo, M. M., Wabule, N. M., Kuria, S., Kibaki, J. M., Onyango, I., Wepukhulu, S. B.,. ... Muthoka, N. M. (2006). Tomato Production Baseline Survey in Kirinyaga District. Kenya Agricultural Research Institute (KARI) Annual Report. Thika, Kenya.

\section{Copyright Disclaimer}

Copyright for this article is retained by the author(s), with first publication rights granted to the journal.

This is an open-access article distributed under the terms and conditions of the Creative Commons Attribution license (http://creativecommons.org/licenses/by/3.0/). 